\title{
Linguocultural features of teaching the russian language as non- native
}

\author{
Nazgul TAIROVA ${ }^{1}$, Nurshashti ALMATOVA ${ }^{2}$ \\ Kazakh National Academy of Arts named after T. Zhurgenov
}

\begin{tabular}{l} 
ARTICLE INFO \\
\hline Article history: \\
Received June 2021 \\
Received in revised form \\
20 June 2021 \\
Accepted 25 July 2021 \\
Available online \\
25 August 2021
\end{tabular}

Keywords:
Russian language,
methods of teaching the
Russian language,
language and culture,
linguoculturological
approach,
linguoculturology,
linguistic and regional
studies,
communicative competence,
linguistic personality.

\begin{abstract}
This article examines the history of the formation of the concept of "cultural linguistics". Through the analysis of the works of scientists, the dependence of the influence of language on the formation and preservation of the culture of the people is revealed, and the reverse process is shown - the acquisition of language skills by studying the cultural characteristics of native speakers.

The article reveals the important role of culturology, cultural linguistics in the system of teaching the Russian language to both its speakers and bilinguals (using the example of groups with the Kazakh language of instruction), as well as foreigners. Using the Russian language as an example, the author analyzes the possibility of using this relationship in teaching methods to increase the effectiveness of learning Russian as a native and non-native language, as well as the successful formation of students' communicative competence. The general features and differences in teaching methods of native speakers of the Russian language, foreigners and those who study the language as a second non-native are given.
\end{abstract}

2181-1415/C) 2021 in Science LLC.

This is an open access article under the Attribution 4.0 International (CC BY 4.0) license (https://creativecommons.org/licenses/by/4.0/deed.ru)

\section{Rus tilini ona tili bo'lmagan til sifatida o'qitishning lingvokultural xususiyatlari}

\author{
Kalit so'zlar: \\ rus tili, \\ rus tilini o'qitish metodikasi, \\ til va madaniyat, \\ lingvokulturologik \\ yondashuv, \\ lingvokulturologiya,
}

\begin{abstract}
ANNOTATSIYA
Ushbu maqola "lingvokulturologiya" tushunchasining shakllanish tarixini o'rganadi. Olimlarning asarlarini tahlil qilish orqali tilning xalq madaniyatining shakllanishi va saqlanishiga bog'liqligi aniqlangan va teskari jarayon - ona tilida so'zlashuvchilarning madaniy xususiyatlarini o'rganish orqali til ko'nikmalarini egallash ko'rsatilgan.
\end{abstract}

\footnotetext{
${ }^{1}$ Candidate of Philology, associate professor Kazakh National Academy of Arts named after T. Zhurgenov, Kazakhstan.

${ }^{2}$ Senior Lecturer, Kazakh National Academy of Arts named after T. Zhurgenov, Kazakhstan.
} 
lingvomintaqashunoslik, kommunikativ kompetentsiya, tilshunoslik.
Maqolada kulturologiya, lingvokulturologiyaning rus tilini ham gapiruvchilarda, ham ikki tillilarda, shuningdek chet tillarda o'qitish tizimida muhim o'rni ochib berilgan (qozoq tilida o'qitiladigan guruhlar misolida). Muallif rus tilini misol qilib, rus tilini ona va ona tili bo'lmagan holda o'rganish samaradorligini oshirish, shuningdek o'quvchilarning kommunikativ kompetentsiyasini muvaffaqiyatli shakllantirish uchun o'qitish usullarida bu aloqadan foydalanish imkoniyatini tahlil qiladi. Rus tilida so'zlashuvchilar, chet elliklar va ikkinchi ona tili bo'lmagan tilni o'rganuvchilarni o'qitish usullarining umumiy xususiyatlari va farqlari keltirilgan.

\section{Лингвокультурные особенности преподавания русского языка как неродного}

Ключевые слова:
русский язык,
методика преподавания
русского языка, язык и
культура,
лингвокультурологический
подход,
лингвокультурология,
лингвострановедение,
коммуникативная
компетенция,
языковая личность.

\begin{abstract}
АННОТАЦИЯ
В настоящей статье изучена история формирования понятия «лингвокультурология». Через анализ трудов ученых раскрывается зависимость влияния языка на формирование и сохранение культуры народа, а также показан обратный процесс - приобретение языковых навыков посредством изучения культурных особенностей носителей языка.

В статье раскрывается важная роль культурологии, лингвокультурологии в системе преподавания русского языка как его носителям, так и билингвам (на примере групп с казахским языком обучения), а также инофонам. На примере русского языка анализируется возможность использования данной взаимосвязи в методике обучения для повышения эффективности изучения русского языка как родного и неродного, а также успешного формирования у обучаемых коммуникативной компетенции. Приводятся общие черты и отличия в методах обучения носителей русского языка, иностранцев и изучающих язык как второй неродной.
\end{abstract}

The methodology of teaching Russian to foreign students, forming in the 20-21 centuries, touched upon the use of the discipline of linguoculturology and linguistic studies for their own purposes. While the object of linguistic and regional studies is the knowledge of culture through language, the object of linguistic and cultural studies is to recreate the mutual influence of language and culture on each other, which is a more extensive field for research than linguistic and regional studies. Based on the analysis of the essence of linguoculturology and linguistic and regional studies, we can conclude that for these sciences the best solution would be to combine them into one new discipline linguoculturology. Based on this, we have studied the ways of introducing into the educational process a more effective linguocultural approach to the study of languages. This approach to date in the methodology of teaching the Russian language by foreign students is considered one of the most effective, focused on the perception and accumulation of a stock of words, the implementation of communication between people belonging to different intercultural communities. 
As for approaches to the study of the native language, here the optimal condition is the implementation of the learner's linguistic personality. Thus, the necessity of introducing a culturological approach into the teaching of the Russian language and for its speakers is substantiated. If we consider the problem of teaching the Russian language from the point of view of a cultural phenomenon, then we should focus on the features of society, its culture, while taking into account the national characteristics of different regions. Therefore, it is necessary to identify cultural values, determine the dominant mentalities, as well as determine the minimum necessary for studying the language of cultural knowledge.

Thus, an appropriate solution would be to introduce into the methodology of teaching languages not only language material, but also the culture of the nation and country. Thanks to the introduction of a linguocultural approach to the development of the Russian language, a linguistic personality is formed. This approach shows the interconnection of language with culture at all stages of the educational process. Studying the cultural characteristics of the people in the process of learning a language helps students to more deeply perceive new language concepts for them.

Based on the foregoing, we began to develop a special system of tasks that would allow us to implement a linguocultural approach in the development of Russian language by Kazakh students. This system is implemented by introducing students to the thesaurus, phraseological units, proverbs, sayings, precedent texts [2], which are carefully selected based on the realities of the traditional and modern cultural life of the Russian people. With the help of special exercises, students can compare Kazakh culture with Russian, on the basis of this, identify related and different links in languages.

It is worth noting that the linguocultural approach to the development of adapted task systems for native speakers, bilinguals and foreign phones is currently an urgent task, attempts to solve which we see in some modern methods of teaching the Russian language. For example, a group of Kazakhstani authors, studying intensive and interactive methods of teaching Russian as a foreign language [3] also introduce a cultural context into teaching methods and techniques, in our opinion, suitable both for the practice of teaching the language to its native speakers and for foreign students. We proceed from the fact that in all cases the common goal is pursued - the formation of the learner's linguistic personality, which is carried out through immersion in culture and its characteristic communications in the practice of language learning.

Based on the common goals, we conclude that the linguoculturological approach is universal for constructing methods of teaching the language of foreign students, bilinguals and native speakers. The only difference is the focus of the training. In teaching the Russian language to foreigners, the implementation of a linguocultural approach requires the interpretation of interethnic communication, a wide range of comparative characteristics. As for teaching Russian to native speakers, the main goal here is to develop a linguistic personality in the course of a deep analysis of the context of native culture. And, finally, during the development of Russian by bilingual students who are relatively fluent in the non-native Russian language, both tasks are combined.

The introduction of a linguoculturological approach to teaching the Russian language carries out educational, pedagogical, mental and educational tasks of teaching. It should be noted that this helps students learn the language in full, getting acquainted simultaneously with the spiritual heritage of another people. Also, this approach promotes the interpenetration of cultures of the Russian nation and, in our case, the Kazakh one. 
When teaching foreigners, the Russian language, it is necessary to take into account various cultural characteristics. You should be aware that this is a bearer of a different culture, a representative of a particular ethnic group, which has a different ethnic consciousness, has a different mentality, its own characteristics and differences. Therefore, the teacher needs to introduce the student to the new culture gradually, reinforcing new images with the help of the formulation of equalities and differences.

In most cases, the barrier to mastering a foreign language is the interfering effect of the mother tongue. When using foreign words, students start from their native national and cultural semantic content. Problems also arise when, when presenting thoughts in Russian, students use the categories and speech structures of their culture. Thus, the interference of the national culture and the national language is an inhibitory element in communication. To overcome the indicated inhibitory factor, the teacher and the student should pay attention to him and, through constant comparisons, bring the differences to a conscious level. Understanding the differences allows you to quickly achieve the desired results in learning a language.

Language is a reflection of the culture of any nation, a vessel that accumulates, retains ideas, cultural knowledge. To preserve the culture, a deep study of the language is necessary, its preservation by native speakers, and ideally, distribution in a foreign environment. For these reasons, when teaching a language as a foreign language, the teacher should make every effort to develop students' motivation, interest, and awareness of the social significance of mastering the Russian language as a way of communication. For this, in the classroom you can apply:

- exercises, the implementation of which requires the involvement of various types of memory, creative abilities, personal experience of students. At the same time, the process and result of the exercises should cause positive emotions;

- instruments of control and self-control of speech activity - for constant checking the level of vocabulary, identifying gaps in knowledge of grammar. Students should be satisfied with their pace of promotion and language proficiency indicators;

- original teaching methods, a wide variety of methods - the novelty allows you to attract attention, arouse interest, which then can develop into a constant interest, hobby, steady motivation;

- a variety of technical teaching aids, on-screen sound media of educational information: educational films, presentations, interactive computer programs, audio recordings, video clips from the Internet and so on - all this helps not only to fully utilize the audio-visual channels of perception of information in the learning process, but also dive deeper into the linguoculturological features of the subject of study.

The student must come to the realization of the fact that without a good knowledge of the Russian language it will be more difficult for him to realize himself in the Russianspeaking space - and this is the territory of the CIS and part of Western countries. Also, one of the important conditions for effective mastery of the language is a positive emotional attitude and a favorable climate in the teaching staff.

The use of the proposed tools, methods and techniques in teaching the Russian language has a favorable emotional effect on the students, helps to direct and coordinate perceptions, expand the worldview, tell more about the cultural life, traditions and customs of the Russian people and, as a result, gives a positive dynamics in the effectiveness of teaching. In addition, the use of the above techniques in the classroom is 
an incentive to deepen knowledge of the language field not only for students, but also for teachers, as the ongoing process of replenishing the methodological piggy bank with new information is launched.

For a linguistic-cultural approach in teaching students Russian as a foreign language, it is necessary to have common language concepts and communicative skills in the teaching methodology, without which there is no way to use any language in communication. Therefore, the study of the Russian language in the aspect of linguoculturology can positively influence the communication style in intercultural communication of students with Kazakh-Russian bilingualism. To accomplish this task, the teacher needs:

- Conduct a selection of linguocultural units of the lexical system for educational purposes.

- Interpret texts, clarify facts and events unknown to students.

- Use fiction as educational tools.

- To work out an effective system of dialogue exercises with a rich content of national-cultural vocabulary.

- Submit material of the linguoculturological aspect during the training in the form of texts for retelling and assignments aimed at improving speech skills identified with national culture.

- To work out an effective system of dialogue exercises with a rich content of national-cultural vocabulary.

- Submit material of the linguoculturological aspect during the training in the form of texts for retelling and assignments aimed at improving speech skills identified with national culture.

- The use of audiovisual materials of a linguocultural aspect reflecting the real features of Russian culture - painting by domestic artists, images of architectural monuments, music, cinematography, dramaturgy, etc.

In conclusion, I would like to note that in the practice of studying the Russian language in groups of students studying in the Kazakh language, the most suitable was the use of visual teaching aids, exercises for the selection of synonyms and antonyms, comparative and descriptive methods with linguistic and cultural comments. These methods were used in combination, complementing and reinforcing each other.

\section{REFERENCES:}

1. Khisamova G.G. Literary text as a means of forming a bilingual personality // Ural Philological Bulletin. Series: Language. System. Personality: Linguistics creative. 2018. No. 2. - PP. 471-476.

2. Tairova N.A. Case-law texts as a subject of intercultural communication // Bulletin of Almaty Technological University. - No. 3 (92) - 2012. - PP. 101-104.

3. Arkabaeva G.S., Kokenova Z.K., Berdalieva T.K. Intensive and interactive teaching methods for RCTs // Bulletin of the Kazakh National Medical University. 2014. - No. 4. PP. 325-329. 